\title{
Rudolph Wagner
}

The events in and around Tiananmen Square in May and June of 1989 can best be understood in the context of a severe and generalised crisis within China's political institutions. That crisis was in part triggered by economic problems following the partial liberalisation and modernisation of China's economy after 1978 , but it was essentially political in character. Indeed, the laws governing the institutional dynamics of socialist states in Europe and Asia are of a very particular brand and require a decisive devaluation of the role of the very factor that has been elevated to a pre-eminent position by Marx himself - the economy.

At most times, and especially in times of crisis, China's political institutions do not operate according to the rules set out in law and in the government's and the Communist Party's formal statements. Instead, they function according to informal rules which render political institutions incapable of adapting and responding to the kinds of change that occurred after 1978, except through the deployment of coercive force. This incapacity of political institutions, together with the fictional character of public discussions of institutional operations, had a destructive impact upon political discourse and the possibility of dialogue between the regime and those in Chinese society who had found a voice in the 1980s. It was impossible for those in power and the Tiananmen protesters even to define each other and to communicate with each other in any meaningful way, and the ghastly results are well-known. To grasp all of this, we need to examine both the condition of China's political institutions and, more broadly, the character of political discourse and political imagination in China.

\section{Unbuilding the Institutions}

It is commonly accepted by all, including Chinese leaders of every faction, that modernisation in bureaucratised economies and societies such as theirs will be a painful process. In the social rearrangements inevitably accompanying this process, conflicts, even violent conflicts, seem unavoidable because the discretionary monopoly of the hitherto ruling group is threatened, and various hitherto privileged groups like workers or cadres are in danger of being marginalised. In the socialist world, these modernising reforms have generally gone through two phases. In the first phase, which China experienced between late 1978 and the mid-1980s, the newly unleashed forces of a liberalised economy secure substantial growth rates and contribute to a general atmosphere of optimism and even buoyancy. In the second phase, which China has experienced since the mid-1980s, the long-term structural problems of these economies and polities make themselves felt; problems that cannot be solved by patching and mending.

During the first phase, things are relatively easy, but in the second phase, the viability of the entire state structure is put to the test. We then discover whether the state is able to manage the inevitable conflicts by protecting contesting social groups from each other's worst (and best) impulses, and whether it is able to channel society's energies in a manner that contributes to the long-term solution of the problems.

China's 1989 crisis did not begin with the army marching into Tiananmen Square. In March, Prime Minister Li Peng had announced an austerity programme to cope with the mounting economic crisis and a return to stronger state control over the econ omy. Indeed, since the inflationary rises in 1987, a sense of crisis had been driven home, especially to the state employees with their fixed salaries and to people in poor agricultural areas far from the cities and trunk lines.

Well before the massacre in and around Tiananmen on 3 and 4 June, the various institutions of the government had ceased to operate normally. The cause was not within the government itself, but rather within the leadership of China's ruling Communist Party. There, various factions and groupings were engaged in a fierce battle for control, the outcome of which would decide the future direction, personnel, and operations of all of the institutions involved. A closer look reveals that even the institutions of the Party Centre were not actually in control. The Party has legal institutions to handle such issues as appointments and policy guidelines, but in times of serious conflict, they instantly collapse, giving way to completely different and highly unpredictable methods.

In this case, the public learned from the Party Secretary, Zhao Ziyang, that in fact control over policy was even beyond his level. In a televised talk with Mr. Gorbachev, Zhao declared that the relations between the Soviet and Chinese parties had not been 
reformalised during their talks - that is, between the two Party General Secretaries - but a few hours before, when Mr. Gorbachev met Deng Xiaoping who held no senior party post. At the Party Congress in 1987 , Zhao declared that the party would refer in all major decisions to Deng and a group of old cadres convened by him. Institutionally, Deng was head of the Party's Military Commission. The other members of this top group like Peng Zhen, Bo Yibo, Wang Zhen, Li Xiannian and Chen Yun are no longer formal members of either the Party Centre or the government, but belong to the various advisory groups who technically have no voting powers. The reason why these old cadres were invited to join in the policy making group was not their institutional importance but the fact that they had built up, over decades, patronage systems in the civilian and military realms which enabled them to bolster their voice with the promise of delivering the support or the opposition of their cohorts.

The viable institutional leaders like Li Peng and Zhao Ziyang thus had little or no discretionary power. The actual decision making was done in a body that had no formal institutional standing, the existence of which was revealed only by a disgruntled Zhao and he was promptly accused of leaking the secrets of the last Party Congress to $\mathrm{Mr}$. Gorbachev. The personal patronage networks which provided the basis for the actual leadership's powers were essentially independent of political beliefs. This type of loyalty is owed in China under the following conditions:

(i) Appointment received under the leadership or by the intervention of the given leader, an example being the heads of the military regions which for the most part have been appointed through Deng Xiaoping's influence in the military commission, and have been selected from his original military unit.

(ii) Work under a given leader; an example being the many people who had worked under the former and now late Party Secretary Hu Yaobang when he was head of the Youth League.

(iii) Admission into the Party on the recommendation of a given leader; $\mathrm{Hu}$ Yaobang provides a good example as he recruited a large part of the present middle-level leadership into the Party through the Youth League.

(iv) Family ties, either through blood or marriage; the details about state president Yang Shangkun's extended family have been widely reported; $\mathrm{Li}$ Peng is Zhou Enlai's adopted son, the new Party secretary Jiang Zeming is Li Xiannian's son-in-law.

(v) Same province of origin; an example is the grouping Deng Xiaoping, Yang Shangkun and $\mathrm{Li}$ Peng, all of whom are from Sichuan province. Another example is the Shanxi clique around $\mathrm{Xi}$ Jianxun. (vi) Graduates of the same class in the military academy, etc.

Institutions, accordingly, have no weight of their own in China. Their role and prestige is a direct function of their head's position in the invisible power structure of the Centre. This stands in radical contrast to a system such as that which prevailed, for example, in the French Third and Fourth Republics. There, dozens of governments manned by different party combinations succeeded one another at a rapid pace, while the professional administrators in the state institutions went on plying their trade, efficiently and unperturbed. Those administrators differed greatly in their political philosophies, but they shared a professional ethic and some political principles, among which was a commitment to basic freedoms and to the ongoing centrality of power under their direction. By sheer inertia, they blocked radical transformations planned by various governments. At the same time, the separation of powers between the courts and the bureaucrats safeguarded the citizens against abuses by the bureaucrats. This diffusion of power among political, legal and bureaucratic authorities was remarkably flexible in responding to the challenge of modernisation in France, mainly because it permitted competing models of adaptation to co-exist and to compete. It also created enough latitude for a more or less rational discourse to occur amid the competition of the various powers and models.

In the People's Republic of China, the structure of politics prevents such a diffusion of power. Technically speaking, it is even illegal. The state constitution contains the Four Basic Principles. These were articulated by Deng Xiaoping himself in 1979, on the basis of a Maoist precedent from the fifties. The Principles are as follows: the leading role of the Communist Party; Marxism Leninism Maoism as the fundamental doctrine; the socialist system as the guiding system for relations of production; and the 'democratic dictatorship of the people' as the instrument to deal with the 'enemies of the people', that is counterrevolutionaries, a category now reserved for the participants in the democracy movement. In practice, this means that the National People's Congress and the government are led by the Communist Party. The Supreme Court and the other courts also operate under the four basic principles so that they must follow the directives of the Party leadership, and the same is true for the various sections of the executive.

In a crisis like the one experienced by the Chinese body politic since 1987, and in particular in May and early June of 1989, the implications of this arrangement become vividly apparent. The separation of powers, which the formal constitutional order appears to promise, does not in fact exist. One day after the Tiananmen massacre, the Supreme Court published a 
statement requesting the speedy arrest, trial and punishment of all those involved in the "counterrevolutionary turmoil'. The potential of the Court to act as a buffer, protecting both the leadership and the people against the hysterics of the other is forfeited. There is no possibility to go to court against the military commanders of the units involved in the massacre or against individual soldiers who wantonly shot pedestrians in the week following 4 June. The Supreme Court did not shirk its real duties in doing this, but exactly fulfilled its duties, namely to follow the leadership of the Party in defining the disturbances as 'counterrevolutionary turmoil' and then applying the 'dictatorship of the people' to the treatment of those involved, which meant execution or long prison terms.

Parliament (or the National People's Congress) might have been a second institution to mediate in the conflict between the leadership and the people. There had in fact been attempts to make it into an instrument for the representation of popular demands. Among the most outspoken theoretical advocates had been Yan Jiaqi, a political scientist with the Academy of Social Sciences. On the occasion of its meeting in March 1989, he petitioned in a published article for it to have a stronger supervisory role vis à vis the government. The budget for the year, he argued for example, is submitted to parliament fully three months after the government has started to act on it. The 1987 budget, furthermore, was changed considerably by the government without any parliamentary consultation. This, he suggested should be changed.

Wan $\mathrm{Li}$, a member of the Politburo, heads the parliament. During the last weeks before the massacre, he was on a visit to the US and Canada. From there, he sent various telegrams in substance approving the demands of the students whom he termed patriotic. He broke off his trip and returned home prematurely, warning his relatives in the US before leaving that he might find himself arrested upon arrival. He was hospitalised in Shanghai and not permitted to go on to Beijing until he had publicly supported the imposition of martial law, and on Wednesday, 8 June, he appeared with Deng Xiaoping and others to congratulate the military for their heroic victory on Tiananmen. He had intended to call a meeting of the standing committee of parliament to discuss the crisis. People set great hopes by such a meeting which legally could have deposed Li Peng. In Nanjing, 600 students began a walk on 1 June over the 1000 kilometres to Beijing to arrive on the scheduled date to present their request to dismiss Li Peng. The preconditions for summoning such a special meeting had long been met, but it was abruptly called off, obviously at the behest of Deng Xiaoping and in spite of legal problems, since Deng is not a member of the body whose meeting he cancelled.
When the meeting eventually took place, an important proposal for a new press law which would have given greater leeway to the papers was taken off the agenda, and the legality and legitimacy of the Tiananmen massacre was never mentioned. Technically, parliament heard without discussion the report by Li Peng, and approved it. Yan Jiaqi, the political scientist who suggested that parliament be made a powerful representative institution is now on the most wanted list for conterrevolutionary crimes. Happily, he has made his way to Paris.

The formal institutions of the executive branch also had next to no influence during this crisis. The Minister of Defence was opposed to the use of the military, but the army was called in by the Military Commission of the Communist Party headed by Deng Xiaoping, overruling the minister who is not a member of this body. Nor were minimal legal norms observed. Police arrested and paraded on television a number of suspected 'counterrevolutionaries'. Charges against them were in many cases legally invalid. One man was charged with 'spreading rumours' which certainly is no legal offence in the Chinese criminal code, but he was jailed. Another man was arrested for having made a speech demanding the abolition of one-party rule. Freedom of speech is guaranteed by the Constitution, but so is the leading role of the Communist Party. He was defined as a counterrevolutionary' which implies a heavy penalty. Within the leadership's understanding of the institutional structure, all of this was precisely according to the law, including the call by the Supreme Court to disregard niceties of legal detail and proceed to a speedy judgement and execution for the criminals.

As to the press, it comes institutionally under the control of the Propaganda Department of the Central Committee, as do the arts including literature, cinema and theatre. The stated purpose of the press is to educate the masses in the spirit of the latest Party directives. Within the leeway allotted by these directives, individual papers can operate without going through central censorship. If, as is the case since the Third Plenum of December 1978, the directive describes bureaucratism as an obstacle to desirable economic development, bureaucrat ism may be denounced. However, since bureaucratism is defined as a left-over from the old society, statements asserting, for example that the state structure set up according to the Soviet model engenders bureaucratism are unacceptable and therefore unpublished. Since the end of the Cultural Revolution a number of institutions have sprung up that could have been legalised. Consider, for example, the independent journals and newspapers. They were a part of the democracy movement between 1977 and 1979. After they had served their purpose by supporting Deng Xiaoping's bid for power against Hua Guofeng, they were outlawed and closed. Some of their authors were 
invited to write for official publications, and others like Wei Jingsheng and Wang Xizhe were jailed or put into labour camps.

This is not to say that there have been no independent publications, rather that the Party Centre continuously kept them in the shadow of illegality and could at any moment intervene when it felt this necessary. The Shanghai-based Shijie jingii daobao. (World Economic Herald) may illustrate this. The paper is edited by the Shanghai Academy of Social Sciences, and has featured some of the more independent reporting and discussion in China in recent years. After failing to support the crackdown in late 1986 and early 1987, six of its editors were fired. When it again failed to toe the Party line after the death of $\mathrm{Hu}$ Yaobang, Jiang Zemin, then Shanghai's Party Secretary and now the new general secretary of the Party, sent a 'leading group' to straigthen out the paper. When the journalists failed to comply, the paper did not appear. The editor-in-chief was sacked long before the army crushed the demonstrations in Beijing. $\mathrm{He}$ was technically accused of 'violating Party discipline'. $\mathrm{He}$ is a Party member, which was the condition for his becoming the editor-in-chief, and by failing to abide by the directives of the leadership he indeed violated Party discipline. $\mathrm{He}$ is an old man already, and has been put under house arrest while one of the younger men actually running the paper is on the most wanted list of intellectuals sought by police for counterrevolutionary activity.

During the days immediately preceding the 1989 crackdown, the content of all published papers shifted daily in direct reaction to who controlled the Party Centre. The head of the propaganda department was Hu Qili, who did not support martial law. Thus the papers reported in a very friendly manner the actions of the students. Li Peng then set up a special media committee consisting of his spokesman and advisor Yuan Mu as well as another man he personally trusted. Although institutionally, this unit had no existence, it took over from $\mathrm{Hu}$ Qili, who also held no government position. It turned the press and television into a desert of official proclamations and denunciations, showing the degree to which the entire media depended on informal channels of control. The authority of the committee was derived from the fact that Deng Xiaoping backed Li Peng. Li Peng backed Yuan Mu, and thereupon a simple Central Committee member overrode a member of the Standng Committee of the Politburo. The state organs played no role whatsoever in this.

It should be clear by now that the new Party leadership after 1978 failed to build institutions that were able to mediate, diffuse or solve conflicts without resorting to the use of tanks, even though these leaders anticipated prolonged and intense conflicts. In fact, the policy of Deng Xiaoping has been less a failure to build such institutions than an active unbuilding of such institutions, even though these institutions were constantly growing in the public imagination. During the post-1978 decade, there was steady pressure for the establishment of such institutions. The parliament or National People's Congress tried to become more than an applause machine for Party decisions; the government organs tried to professionalise themselves and become less dependent on day-to-day Party directives; the papers tried to diversify and develop in new and more independent directions. And there were demands to make the courts less dependent on Party directives. All of these trends reflected a tendency visible, and in small part, accepted in the economic realm. They cried out for an institutional lease of life. Their institutional consolidation, however, has been actively prevented, to the extent that even accepted institutions of government and the Party Centre were undermined by way of secret decisions which ensured that actual powers rested in the shadowy world of the retired old men around Deng Xiaoping.

In them, the problem of the Chinese state structure is epitomised. Most of them hold no direct institutional position at all, but wield their power through patronage networks. The huge importance of individuals and the unimportance of institutions in China today is vividly apparent here. The successful pursuit and implementation of a policy depends not upon the strength and weight of the institution promoting it, but rather upon the person advocating it, and it will fall with the demise of this person.

\section{Political Discourse and Political Imagination at Tiananmen}

A similar distance separates appearance from reality in the workings of another key political institution, the Communist Party. And as we shall see, this and the charades discussed above have done enormous damage to political discourse and to channels of communication between state and society. The Party's constitution outlaws the formation of cliques or factions. As everyone knows, however, these factions exist and form the main organisational structures of power. This ban on forming factions means that the operation of the various factions is driven into a verbal underground. No one can claim adhesion to a certain faction as his reason to operate in a certain way; activity which is perfectly possible in a multi-party system. No one can claim the interests of a certain part of the population as a rationale for his or her policies. The legitimacy of controversial discourse in public as well as within the Party is thereby eliminated. In a Party of some 48 million members it can be assumed that the various interests in society, be they geographically or socially based, will be represented - an argument in fact advanced by the leadership against the necessity of a multi-party system. 
However, the lack of legitimacy for advocating particular and even parochial interests openly, and the heavily enforced and verbalised homogeneity of the Party do not permit such a representation of interests.

There is always and in any polity a strong tension in politics between the rationale given for a policy or decision and the complex motives and compromises actually going into the decision. Still, the appearance of rationality is maintained and any demonstration that the official reasons were by disguises for ulterior interests is often considered devastating. Under Chinese institutional conditions, the conflict between the official rationale and the actual decision-making process is as fundamental as it is illegal to mention it publicly. The Hong Kong and Taiwanese papers, from a greater familiarity with cultural patterns, base all of their political analysis on the factions and alliances formed under the above-mentioned criteria. Therefore, they are illegal contraband in China. Even if their perceptions are not altogether correct, these assumptions certainly inform the reading of the Chinese public and its political class.

The political discourse of the country is soured by this perception. Any news, any argument profferred, theory proposed or historical fact challenged is read as a potentially devious expression of some political purpose, and thereby stripped of its claim to rationality, which in turn would have made it challengeable on rational grounds. The political discourse is thus driven into the verbal underground of silent, symbolical or coded communication. While Pekinology might be an esoteric field in the West, it certainly is mass fare in China. Does a leader wear Western clothes or the Sun Yatsen suit? What type is used to set a specific article? Who is photographed with whom in published photographs, and how do the persons photographed look at each other? Is there a difference between the printed and the performed version of a theatre play? The forms of esoteric communication developed to discuss controversial political issues are as old as they are endless in their variety.

In point of fact, China's institutions have been most effective over the decade leading up to Tiananmen at divesting themselves of their discretionary powers. Their partial self-dismantling freed substantial social forces that threw themselves into modernisation. The drive for this partial divestment of discretionary powers emanated from the reform leadership itself, and therefore was not in need of mediating institutions. The conflict, however, between the independent aspirations of parts of the populace and the Centre was constantly present, although only in a latent form. The various political campaigns against spiritual pollution and bourgeois liberalisation during the last decade showed a slowly rising temperature in the contention. But when the Party Centre was confronted by the Beijing population and a substantial part of the political class with independent criticisms of mismanagement and demands for institutional reform that would have transformed a paternalistic command structure into a contractual structure, this self-dis mantling by Party and state institutions left no structures through which to communicate, to mediate and to engage both sides in a negotiated settlement.

As this crisis developed, it turned out that both sides assumed and perceived the essential and, as far as the Party was concerned, deliberate inability of China's state and Party institutions to handle the stresses of modernisation and adaptation. This came as more of a surprise to Westerners used to the roles played by their own institutions rather than Chinese conditions. The protesters never seriously tried the institutions, and the Party Centre treated them with the same disdain by languidly discarding them. And the members of the institutions themselves, well aware of their marginal existence, ceased to function even in their limited ways. The massive body of state and Party institutions with their officials, papers, forms and language, with stability and continuity suggested by their sheer size and weight, turned out to be rather ethereal and highly unstable structures. They were subjectively and objectively unable to adapt to the new challenges from below, and they were paralysed by the dissonance in the Party Centre itself.

Both sides were thus stranded for the occasion in an institutional desert, facing each other on Tiananmen Square. They had no well established categories with which to define each other and each others' actions, and to communicate with each other and the public at large. Confronted with this situation they were searching in the imaginary stock of their historical and social experience for the words, the precedents and the model actions to express their concerns, to prop up their spirits and to earn themselves some legitimacy.

The students had a substantial problem defining themselves. Many of them wore the white headbands popularised by the Japanese, Koreans and Philippinos. In the Chinese context this meant that they were not an organisation challenging the Communist Party, but the unarmed and non-violent masses articulating their basic aspirations. At the same time, this device likened the government to the Marcos regime, a brutal dictatorship basing its power on a mighty military machine and characterised by an extreme degree of personal corruption. Their legitimacy came from world opinion which had denounced Marcos, and their perspective and hope from the Philippinos' peaceful transition to democracy. In Beijing University, a photo exhibition in April and May showed many pictures from the Philippine revolution, by way of precedent. Institutionally, this was a very broad and a very foggy construct taken from the imaginary world of the foreign post-socialist revolutions. 
Their organisational forms - that is, the independent unions of the students, the workers and the intellectuals - were taken from another stock, the Polish Solidarnosc experience. This implied an entire scenario, namely the broad and nearly complete popularity of the movement, the potential for a brutal crackdown such as that perpetrated by General Jaruselski, and the final demise of Jaruselski's socialist junta a few years later. The Solidarnosc model assumed that the military and the Party would be willing to go along with a crackdown. It contained an ironic dialogue with Deng Xiaoping himself. On the occasion of the last major student protest, in December 1986, Deng had spoken approvingly of Jaruselski for having saved the Poles from their own self-destructive urges through his intervention. Coming back to the Polish experience in 1989, with the dramatic changes in Poland happening exactly at the height of the conflict in China, the students and workers took Deng at his own word by projecting what would happen to him if he copied Jaruselski.

Of course, China is neither Poland nor the Philippines, but in this manner the students saw themselves and portrayed themselves as part of an irresistible world trend. The hunger strike as the ultimate means of pleading for a rapid and serious dialogue was another imported symbol. The standard song of all participants in this movement was, strangely enough, the Internationale. Those who sang it were not aware that the song referred to the Communist International, but read the entire text afresh. Read unhistorically, it is indeed a song where the damned of the entire earth encourage each other to fight for the days of glory to come, socialism and communism not being mentioned. The song thus undermined the Communist Party's claim of having achieved a revolution which solved all problems. Tactically, it permitted the singers to stay within the confines of state-ordered communist discourse. These modern and foreign models were important and useful, but they only integrated a much older Chinese tradition with the imaginary of the world.

Some 60,000 students from all over the country converged on Beijing to support the Tiananmen Square occupation, which for a long while was the only important thing to happen. Many later actions in the regions were explicitly undertaken in support of the Tiananmen Square action. The Square was chosen not only because it is a big place near the seat of the Party Centre with large crowds coming by, but primarily because it is the symbolic centre of the nation. The heroes who had died for the revolutions since 1840 had their monument on its central axis, and behind it stands the Mao Zedong Memorial Hall dedicated to the ideological mainstay of the republic. The axis running through Tiananmen is again older than the People's Republic. It goes back to the last two dynasties. The emperor sat on this axis facing south, and the new rulers have taken his place on the Tiananmen gate, facing south on solemn occasions. By occupying the Square, the students and citizens held the heart of the nation and symbolised their representativeness which they could not demonstrate through opinion polls or elections.

There was no particular directionality in the occupation of the place. But when the conflict sharpened during the last ten days before the crackdown, the students from the arts institute built the statue of the 'goddess of democracy' there. It was stationed right on the imperial axis, being the first structure on this axis seen from Tiananmen Gate, and it faced north. Two other structures also broke the north-south orientation of the axis, and presented some sort of challenge to the Centre's leaders' place on Tiananmen Gate. The Heroes Memorial raised the question of whether they had kept faith with the many who had given their lives; Mao Memorial hall raised the issue of whether Deng Xiaoping was still loyal to the Chairman's legacy. Placing the goddess of democracy in front, and facing north, challenged the leaders with a new notion of primordial and international importance-democracy. In the appeal inscribed on the streamer next to this goddess, as well as in some articles, it was made clear that this goddess represented the aspirations not just of the Chinese, but of the Asian peoples' quest for democracy, reinforcing the Philippine connection. The statue again defined the imaginary other as the feudal, autocratic and militaristic authority in the palace of the Party Centre. In fact, the palace today is only a museum and an amusement park. The offices of the Centre are to the left in Zhongnanhai. But Tiananmen had been depicted as the heart of the nation in poems, on stamps, in guidebooks, and at the beginning of each evening's television news. If the palace was not the actual seat of the Centre, there was an imaginary emperor sitting there and being challenged.

There is an old tradition in China, according to which officials and commoners, even foreigners could gain direct access to the emperor in case of a great wrong. They would proceed to the entrance of the palace, where there was a big drum, the dengwen zhi gu, the drum that can be heard above. They would beat the drum, and a censor on duty would come running out, take the writ, and bring it straight to the inner quarters of the emperor who would have to deal with the matter with great dispatch. The institution was a safeguard in moments of institutional collapse. Only people who had tried all other avenues of remonstrance and redress and had failed to right the wrong were allowed to use this last instrument. The occupation of Tiananmen Square straight in front of the imaginary palace door, and the demands to the government voted upon in that place were presented to the government in the language of a largely imaginary 
imperial institution. All institutions had been tried, they had failed to right the wrong (usually corruption), so now the emperor and the common citizen had to confront each other directly. The demand for direct and continuous dialogue between citizens and government leaders (that is, $\mathrm{Li}$ Peng or other members of the Politburo) only epitomised the perceived absence and/or collapse of mediating institutions.

The death of the former Party secretary Hu Yaobang played an important role in triggering all of this. In March, there had been a resolution calling for the release of Wei Jinsheng and other political prisoners, signed by many and prominent intellectuals, a first in the history of the People's Republic. There had been signs, however, that Hu Yaobang was coming back. He had not been dismissed from the Politburo, and in March, Zhao Ziyang had himself photographed with him and had the picture printed in the People's Daily. After a bitter controversy in the Politburo, $\mathrm{Hu}$ Yaobang died of a heart attack. In the personalised structure of Chinese politics, where the individual leader counts for infinitely more than the institution he might be heading, $\mathrm{Hu}$ Yaobang seemed to be the only top leader with a record qualifying him to guide the country through the crisis. He had been head of the Youth League for decades, and in this function had promoted a good number of fairly outspoken young men and women into the ranks of the Party. He had managed the rehabilitation of the victims of the Cultural Revolution and of the Anti-Rightist Campaign. He had suggested most of the more daring new slogans like 'seeking truth from facts' and had supported a much stronger divestment of Party control over government affairs. In addition, he was one of the very few leaders about whom no stories of nepotism circulated. His death closed what people saw as the last personal avenue of communication open to handle the economic and social crisis of the country.

The occupation of Tiananmen began with the unofficial mourning ceremony for $\mathrm{Hu}$ Yaobang. Next to his large portrait that had been dedicated by the arts college students and hung on the Heroes' Memorial, another smaller picture was mounted. It showed $\mathrm{Hu}$ Yaobang with the inscription. 'China's Bao Longtu'. Bao Longtu was a judge under the Song dynasty. Known for his daring uprightness, sense of justice and willingness to listen to the complaints of the common people, he had become a proverbial figure with many traditional operas depicting his exploits. Two huge streamers, appended to balloons, floated on the Square mourning $\mathrm{Hu}$ as 'Zhongguo zhi hun', the soul of China.

On the same day that this unofficial mourning took place on Tiananmen, three student leaders proceeded to the Great Hall of the People where the official mourning ceremony was held. They knelt down in front of the door, knocked their heads on the floor, and asked to see the Prime Minister in person. They remained there for three hours. Li Peng refused to see them. In terms of symbolic action in a world where all sides see each other only as embodiments of imaginary constructs, the three student leaders scored an important point. They had stressed the urgency of the crisis and maintained an unquestionably non-violent and non-threatening posture, thereby proving the purity of their motives and methods. Had Li Peng received them, he would have accepted their claim. By not receiving them, he made the public accept it and made himself appear to be a corrupt minister presiding over the last and desperate hours of a waning dynasty, like a well-known figure from the Southern Song. Through this symbolic encounter, Li Peng was transformed from an awkward Soviet-trained engineer into an historical monster.

The students were using historical forms from the Han and the Song dynasties - when student demonstrations against corrupt government broke out - that had been vindicated by history although those demonstrations had often been brutally suppressed. The students' performance as historical actors in roles from the stock of a hybrid imagination appears to have been highly successful in mobilising the hybrid imagination of the wider modern Chinese public, with its combination of traditional and Western images. The Party Centre was in greater trouble in its imaginary role playing. It operated on the traditional assumption that people are by nature greedy, egotistical and oblivious of national interests, and therefore in sum self-destructive if left to their own devices. The idea is best expressed through the standard metaphor used by the old imperial officials for the people. The people are like river waters. In China, the great rivers are diked up, and if they break through the dikes, much disaster and destruction follows. They revert to their productive function only after a strong hand has forced them back behind the dikes of virtue. Economic liberalisation after 1978 had whetted their material appetites and they became receptive to Western ideas which support this moral depravity instead of combatting it.

In their view, the worst disasters happen when leaders in the Party Centre tolerate, support or even encourage such spontaneous and irresponsible outbursts instead of suppressing them. This happened during the Cultural Revolution when Mao supported the Red Guards. It happened in late 1986 when $\mathrm{Hu}$ Yaobang refused to clamp down on the students, and it happened in 1989 when Zhao Ziyang opposed the use of the Army to restore calm. In the perception of Deng Xiaoping, China is an extremely unstable entity. Stability cannot be established through a contract between governing and governed, but only through paternal authority, which uses strict punishment as an educational device. The standard formula for the traditional bureaucrat's relationships with the people 
was that he was to be the "father and the mother of the people'. The Party Centre sought to take on this role. Relationships between parents and their children in China are not contractual, but give full authority and responsibility to the parents. Thus the Centre sent money to treat the students on hunger strike, and visited them in the hospital, and even on Tiananmen. They called them constantly 'our beloved children', implying their immaturity and need for parental control.

This aspect was combined with utmost rigidity in matters of political substance. The crackdown with tanks and machine guns fits in as the fatherly punishment within this metaphorical construct. The means used were not dictated by the visible threat posed. A dike breaks because first a little dribble of water leaks out. If this hole is not plugged, the destruction will be immeasurable. The means used on Tiananmen were chosen with regard to an imaginary outcome, not with regard to the few hundred students who were still there on Saturday, 3 June, and who furthermore had voted the day before to go back to school on Monday. The crackdown was eventually jusified, in a translation into modern language, as one directed against a 'counter-revolutionary' onslaught.

Both sides in this crisis drew and draw on a common stock of imaginings, in terms both of institutions and experiences. This recourse to the imagination in crafting and instrumentalising one's role and perceptions is not unique to China. What is distinctive, however, is that this imaginary and symbolic interaction offers no mechanism in the real world which might deflate the oversized mutual perceptions, and the actions based thereon, and link them to the sober ambiguities of real life. The Chinese Communist Party has all too neatly slipped into the roles and metaphors of the traditional state and has with devastating efficiency eliminated all those entities that could help to navigate through the crisis. It is a bitter irony now to hear it said that without the leadership of the Communist Party, China would be done for.

A caricature in the Shanghai Xinminwan bao in late May, 1989, showed an axe proudly standing amidst felled trees, proclaiming itself to be the only operative entity. 